Babeş-Bolyai

University

Cluj-Napoca

\title{
TRANSYLVANAN REVIEW
}

\section{OF ADMINISTRATIVE SCIENCES}


Authors must send one electronic copy to Cristina Mora (cristina@rtsa.ro)

Submission of a manuscript will be held to imply that it contains original unpublished work and is not being submitted for publication elsewhere at the same time.

The language of the journal is Romanian (when the use of diacriticals is required) or an international language (English, French, German, Italian, Spanish, etc.). All submissions must have a title, be 1,5 lines spaced, have a margin of $2 \mathrm{~cm}$ all round, be between 7 and 25 pages long, be written in Times New Roman Style, have 12 points characters, and must start with an alignment.

- The title page must list the full title, short title of up to 70 characters, names and affiliations of all authors, their qualifications, their post and their current appointment if different. Give the full address, including email, telephone and fax, of the author who is to check the proofs.

- Supply a long structured abstract written in English, of up to 200 words for all articles (except book reviews). This is to enable readers, to get a comprehensive picture of the main issues of the study and its impli-cations without reference to the text. The authors are requested to summarize very clearly the contents and implications of their study, following properly the structure of the different subsections:

Background, Aims of the Study, methods, Results, Discussion (with limitations of the study), Implications for Policies, Implications for Further Research) on the basis of the particular features of their article, in order to enable the readers of different cultural backgrounds and countries to easily follow the main issues of the study. It should contain no citation to other published work.
TEXT

\section{Abbreviations}

All abbreviations should be written in full the first time they appear. Mathematical symbols may be either handwritten or typewritten. Greek letters and unusual symbols should be identified separately in the margin. Distinction should be made between capital and lower case letters; between the letter $\mathrm{O}$ and zero; between the letter 1 and the number one and prime; between $\mathrm{K}$ and Kappa.

\section{REFERENCE STYLE}

References should be provided either in Harvard or Chicago manual style.

All references must be complete and accurate. Online citations should include date of access. If necessary, cite unpublished or personal work in the text but do not include it in the reference list.

\section{FURTHER INFORMATION}

Proofs will be sent to the author for checking. This stage is to be used only to correct errors that may have been introduced during the production process. Prompt return of the corrected proofs, preferably within two days of receipt, will minimise the risk of the paper being held over to a later issue.

\section{LETTERS TO EDITORS}

This section is aimed at encouraging a lively interaction between readers, authors, editorial board and publisher. Letters should refer to articles published in the journal. They should not exceed 500 words and there should be no more than five references. Letters will be edited for clarity and conformity with Transylvanian Review of Administrative Sciences style, and may be shortened. Proofs will not be sent to authors.

\section{BOOK REVIEWS}

The journal will publish both book reviews and lists of new book titles considered of relevance for those interested in public administration. 


\title{
Transylvanian Review of Administrative Sciences
}

\author{
No. 58 官 / (O)ctober / 2019
}

\author{
Senior Editor: Călin Emilian Hinţea \\ Director: Ciprian Tripon \\ Editor: Cristina Mora \\ Administrative director: Ovidiu Boldor \\ Editorial Board: Balogh Marton, Daniel Buda, Marius Dodu, Dacian Dragoş, Călin Ghiolţan \\ Veronica Junjan, Dan Lazăr, Elena Minea, Natalia Negrea, Liviu Radu, Sorin Dan \\ Şandor, Bogdana Neamţu, Bianca Radu, Raluca Gârboan, Adrian Hudrea, Cornelia \\ Macarie, Dan Balica, Tudor Ticlău, Cristina Haruţa, Horia Raboca, Raluca Suciu, Ana \\ Elena Ranta, Octavian Moldovan, Alexandru Pavel
}

\section{INTERNATIONAL ADVISORY BOARD}

Carole NEVES, Smithsonian Institute, Washington, DC

Allan ROSENBAUM, Florida International University

Arno LOESSNER, University of Delaware

Roger HAMLIN, Michigan State University

Laszlo VARADI, Corvinus University of Budapest

Eric STRAUSS, Michigan State University

Gyorgy JENEI, Corvinus University of Budapest

Adriano GIOVANNELLI, Genoa University

Bernadine Van GRAMBERG, Victoria University

Julian TEICHER, Monash University

Geert BOUCKAERT, Catholic University of Leuven

Veronica JUNJAN, University of Twente

György HAJNAL, Corvinus University of Budapest

Taco BRANDSEN, Radboud University Nijmegen, Secretary-General of the European Association for Public Administration Accreditation (EAPAA)

Juraj NEMEC, Masaryk University, president of The Network of Institutes and Schools of Public Administration in Central and Eastern Europe (Nispacee)

Maria ARISTIGUETA, University of Delaware

Yüksel DEMIRKAYA, Marmara University

Marian PREDA, University of Bucharest

Marius PROFIROIU, Bucharest Academy of Economic Studies

Alexander HENDERSON, Long Island University

Gregory PORUMBESCU, Northern Illinois University 
Transylvanian Review of Administrative Sciences has been selected for coverage in Thomson Reuters products and custom information services. Beginning with no. 22E/2008, this publication is indexed and abstracted in the following:

1. Social Sciences Citation index®

2. Social Scisearch ${ }^{\circledR}$

3. Journal Citation Report/Social Sciences Edition

Transylvanian Review of Administrative Sciences is also listed in EBSCO, IBSS - International Bibliography of Social Sciences, Elsevier Bibliographic Databases, PA@BABEL Public Administration's dataBase for Accessing academic publications in European Languages and DOAJ - Directory of open access journals. 


\section{CONTENTS}

Mojca BIŠČAK

Jože BENČINA

5 The Impact of HRM Practices on the Performance of Municipalities.

The Case of Slovenia

Oana Maria BLAGA

Răzvan Mircea CHERECHEȘ

Cătălin Ovidiu BABA

24 A Community-Based Intervention for Increasing Access

to Health Information in Rural Settings

Emil BOC

38 The Development of Participatory Budgeting Processes in Cluj-Napoca

Andrei CHIRCĂ

Dan Tudor LAZĂR

52 Students's Visitors - Among the Unexplored Types of Local Tourism?

Min-Hyu KIM

65 Factors Influencing the Propensity to Contract Out Health and Human Services in Response to Government Cutbacks: Evidence from US Counties

Mateusz LEWANDOWSKI

85 Organizational Drivers of Performance Information Use:

The Perspective of Polish Local Governments

Romea MANOJLOVIĆ TOMAN

Goranka LALIĆ NOVAK

100 The (Lack Of) Demand for Performance Information by the Croatian Parliament Oleksiy POLUNIN

116 The Case of Ukrainian Corruption: Phenomenology and Psychological Insides 


\section{THE (LACK OF) DEMAND \\ FOR PERFORMANCE INFORMATION BY THE CROATIAN PARLIAMENT}

\section{Romea MANOJLOVIĆ TOMAN \\ Goranka LALIĆ NOVAK}

\section{Romea MANOJLOVIĆ TOMAN}

Assistant Professor, Department of

Administrative Science, Faculty of Law,

University of Zagreb, Croatia

Tel.: 0038-514-890.247

E-mail: romea.manojlovic@pravo.hr

\section{Goranka LALIĆ NOVAK}

Associate Professor, Department of

Administrative Science, Faculty of Law,

University of Zagreb, Croatia

Tel.: 0038-514-890.208

E-mail: glalic@pravo.hr

\section{Abstract}

This paper explores the demand for performance information by members of the Croatian Parliament, and the supply thereof by the Croatian public administration. The research consists of data content analysis of parliamentary questions and answers in the first six months of 2015. The results show that the demand for performance information by MPs is lower than its supply by the administration. The MPs' personal characteristics have an influence on the demand for performance information since higher demand is shown by those belonging to opposition parties, while those most experienced politically are the ones requesting least information. The influence of MPs' education on the demand for performance information is not unequivocal. Two issues are further discussed: development of the performance management system and an increase in the power of executives, which can be a result of the Europeanization process.

Keywords: performance information, demand, supply, MPs, Croatia. 


\section{Introduction}

Performance management can be seen as consisting of three broad components: the pure measurement of various performance dimensions, the incorporation of information into the management and policy cycle, and the proper use of that information (Van Dooren, Bouckaert and Halligan, 2015). Although measurement alone does not ensure the use of performance information (PI), it is necessary for the information to be supplied to potential users (de Lancer Julnes and Holzer, 2001).

There are different potential users, who can generally be classified into three groups: public managers, politicians and citizens (Van de Walle and Van Dooren, 2011, p. 3). The literature offers a number of examples of research on the use of PI by public managers (see, for example, Moynihan and Panday, 2010; de Lancer Julnes and Holzer, 2001; Hammerschmid, Van de Walle and Štimac, 2013). Although some research has been conducted on the use of PI by MPs (Askim, 2009; Askim, 2011; ter Bogt, 2004; Raudla, 2012) this subject receives less attention than managers' use of PI (Pollitt apud Askim, 2011; Talbot apud Askim, 2011, p. 130; Raudla, 2012, p. 1000). A similar case applies to the research on the use of PI by citizens (Van de Walle and Roberts, 2011; Mason, Hillenbrand and Money, 2014).

Performance management has received considerable attention from researchers and practitioners, but research in Anglo-Saxon and Scandinavian countries prevails (Boyne apud Hammerschmid, Van de Walle and Štimac, 2013, p. 3). The amount of research dealing with East and Central European countries is considerably smaller (for a review of research, see Dan and Pollitt, 2015, pp. 1321-1324).

This paper examines the demand for PI by MPs and its supply by the public administration. Given the above, it should contribute to knowledge about MPs as potential users of PI. Methodologically, the paper is based on data content analysis of all MPs' parliamentary questions and the answers of executives in the first six months of 2015. This methodology has already been successfully used in another research (see Van Dooren, 2004). After this introductory chapter, the research hypotheses, methodology, and research results are presented and discussed.

\section{Research hypotheses}

In the context of this research, the supply of PI is the task of public organizations which are responsible for setting up performance measurement systems and for providing MPs with adequate information which can, possibly, be used for different purposes. On the other hand, MPs can demand PI and possibly take action based on the information received. Ideally, there should be a perfect match between the demand and supply of PI - whenever MPs require the information, it should be provided. However, the mismatch between demand and supply of PI can happen in both directions. It is possible for the supply of information to be higher than the demand if the public administration measures the performance and provides information in various forms, even though the information was not requested by the MPs. If the demand 
is higher than the supply, the MPs require information on various performance dimensions, but do not receive it and thus do not use it (Van Dooren, 2004, pp. 513-515).

When it comes to performance measurement in Croatia, the recent 'Strategy for the Development of Public Administration 2015-2020' (Official Gazette 70/15) states that one of the basic problems of Croatian public administration is the lack of supervision over its functions. There is no coherent system of performance measurement, and therefore it is difficult to track whether the central state administration or local units have achieved the planned results.

Nevertheless, there are some policy documents and regulations which have introduced the obligation of performance monitoring. According to the Budget Act (Official Gazette 87/08, 136/12, 15/15), all central state bodies are obliged to prepare three-year plans that should contain output and outcome indicators. The Ministry of Finance (MF) publishes guidance on the structure of these documents, and semi-annual and annual reports on the execution of strategic plans have to be presented to the MF and the Ministry of Regional Development and EU Funds (MRDF).

The basic notion of the performance management doctrine requires the delegation of managerial responsibility to professional managers inside public organizations who are held responsible for the results they produce (Moynihan, 2008). Croatian public administration is characterized by a high level of political appointments (Koprić et al., 2014, pp. 381-382), which impedes the creation of a category of real public managers and the development of a proper performance management system. Consequently, although the Public Internal Financial Control Act (Official Gazette 78/15) requires organizations to introduce a financial management and control system and to strengthen managerial authority, according to MF reports (Ministry of Finance, 2012, pp. 8-11) there are many shortfalls: the system of managerial responsibility is still not functional, financial control is mainly input oriented, and the set goals are undefined and difficult to measure.

At the very end of 2017, the new 'Act on the System of Strategic Planning and Development Management' (Official Gazette 123/17) was enacted, requiring all public organizations to engage in a comprehensive strategic planning process which includes the use of performance measurement. However, most parts of the new law will become operational in 2019 and 2020. Additionally, the State Audit Office, apart from its regular financial revisions, is starting to conduct performance reviews of various issues, and these reports are submitted to Parliament.

Generally, the Croatian public administration is advancing in the performance measurement system, and is able to produce some PI. When it comes to the supply of PI to Parliament, according to the Standing Orders of the Croatian Parliament (Official Gazette 81/13), the Government has an obligation to submit annually an oral report on its work (art. 128). Additionally, Parliament or its working bodies are entitled to request additional information from all state bodies (art. 127), and individual MPs can pose questions to ministers. 
However, the question is if there is interest by MPs to demand PI. Research examining types of accountability in Croatia (Lalić Novak, Manojlović and Džinić, 2015) has shown that accountability in the Croatian public sector is input oriented, and traditional models of accountability still prevail, with accountability for performance lagging far behind. This finding seems to indicate the potential low interest of MPs in demanding and using PI for accountability, but probably also for other purposes.

This conclusion can be supported by the results of other researchers. Although the topics examined vary and the countries in question differ considerably from Croatia, the results can give an indication of what to expect in Croatian circumstances. Research encompassing six western European countries (Finnish Ministry of Finance, 2013, p. 9) has shown that 'demand for high-quality evidence [including PI] is often a larger problem than its supply', and that the role of legislators in creating evidence-based policymaking has been rather neglected. Van Dooren, Bouckaert and Halligan (2015, p. 121) offered a review of research proving that parliaments, although supplied, have difficulties in using PI. Based on a comparative study of performance budgeting in seven OECD countries, Sterck and Scheers (2006, p. 60) listed four major conditions for the success of performance budgeting reforms, where the necessity to create legislative interest in performance (and consequently PI) is listed as the second one, providing evidence that there are problems with the demand side of PI. Only in Belgium has it turned out that demand for PI is slightly higher than its supply (Van Dooren, 2004). Thus, the following hypothesis is formulated:

(H1) Demand for performance information by MPs is lower than the supply of performance information by the administration.

The second question relates to the characteristics that differentiate MPs that demand PI from those that do not ask for such information. There are different ways to select the MPs' characteristics that can be examined. For example, when researching managers' use of PI, Moynihan and Pandey (2010) used the categories of individual beliefs, job attributes, organizational factors and external factors. Askim (2011) explains differences in PI usage by politicians, taking into account their political background, role characteristics, political ideology, polity characteristics, and policy sectors.

This paper follows Askim's division where two personal background characteristics of MPs (educational level and political experience) and one role characteristic (affiliation to a ruling or opposition role in parliament) are empirically examined.

Askim (2009) has shown that some factors are relevant for PI demand by Norwegian local councilors: frontbenchers and politically inexperienced councilors tend to seek PI, while the best-educated councilors search less for PI. Affiliation to ruling or opposition parties does not appear to be relevant. In Estonian circumstances, Raudla (2012) has shown that PI is less used by more experienced MPs, while affiliation to ruling/opposition parties has again not shown itself to be of importance.

In 2015, performance measurement could be considered to be a novelty in Croatia, and so it is expected for MPs to have low technical and practical knowledge of the 
performance management system. Although they can rely on their staff, MPs should have basic knowledge of the existence of PI and how the information can be used. Thus, it is expected that MPs with a higher level of education who presumably have better chances of being acquainted with the concept of performance measurement might demand more PI than those with a lower level of education.

It is expected that politically inexperienced MPs will demand more PI than those with more experience. Askim (2011, p. 136) stated that politically inexperienced councilors seek PI because this is the type of information they have unlimited access to. In addition, they feel more insecure when faced with decision dilemmas and expect PI to help them. The same can be applied to Croatian MPs.

Although not proven in Norway (Askim, 2009) and Estonia (Raudla, 2012), in Croatia higher demand for PI can be expected from MPs belonging to opposition parties. Moynihan (2009) points to four potential uses of performance information. One is political use since PI can be employed both by government parties to show the success of government policies as well as by opposition parties to show their failure. According to the first hypothesis, the Croatian public administration is expected to (over)supply MPs with PI. Thus, MPs belonging to the ruling party will not be stimulated to request PI, while MPs of opposition parties will be stimulated to demand additional PI in order to show weaknesses in the government's work. Consequently, the second hypothesis can be formed:

(H2) MPs with a higher educational level, politically inexperienced MPs and those belonging to opposition parties will demand more performance information.

\section{Methodology}

Based on Van Dooren (2004), the methodology employed in this paper includes data content analysis of all parliamentary questions of MPs posed to the Government, the Prime Minister or relevant state departments in the first six months of 2015, and the answers to these questions.

This research uses the simple input-output-outcome model. According to this model, organizations have certain inputs (for example, financial and human resources), which are, through various activities, used to produce the desired outputs (goods and services). However, in the public sector, outcomes are of the utmost importance. Outcomes are considered to be 'everything beyond outputs' (Bouckaert and Halligan, 2008, p. 16). Outcomes are produced by outputs, but the environment has an influence on their final outlook. Outcomes can be divided into intermediary (usually in the short term) and final (usually in the long term) (Van Dooren, Bouckaert and Halligan, 2015, p. 24).

Based on this classification, all questions and answers were assessed to establish: (1) whether MPs demand information on the used inputs, produced outputs and/or achieved outcomes (demand for certain PI); and (2) whether this information is provided in the answers provided by the administration (supply of certain PI). 
In addition, the quantitative connection between the demand and supply of PI was studied, examining whether the answer contains the precise amount of information demanded in the question, or more/less information.

In order to establish the MPs' characteristics, the following data were extracted for each MP: (1) education level (secondary school education, three-year vocational education, university degree, higher academic titles); (2) political experience (serving less than one term in Parliament - substitutes for MPs elected to positions in government and administration, serving the first full term, serving two terms, serving more than two terms); (3) belonging to the ruling parties/independent MPs supporting the government, or parties in opposition/independent MPs in opposition.

All questions were analyzed by both authors, and the level of congruence between the coders exceeded $80 \%$ which indicates that the collected data are representative. The received data were analyzed with the methods of data inspection and descriptive statistics.

Additionally, a qualitative view on the questions and answers containing PI is given in order to provide further insights into the quality of the questions and answers. This was not used to verify the hypothesis but only as a subsidiary method to provide insight into the quality of the questions and answers.

Although interviews would be the preferred research methodology when examining PI usage (Raudla, 2012, p. 1001), this paper examines only the demand and supply of PI. Therefore, a quantitative content analysis seemed to be appropriate since it allows for the retrieval of objective information without any interference (and thus possible fabrication of the data) from both the demand and supply side (Webb et al. apud Weber, 1990, p. 10).

\section{Results}

A total of 238 questions were posed in the period of the first six months of 2015. Out of that number, 32 questions had to be excluded from the analysis either because there was no answer to the question, the question itself was not uploaded to the official Parliament website ${ }^{1}$ or the question was not available on account of personal data protection. Therefore, a total of 206 questions/answers were examined.

First, the questions/answers which requested/contained PI were extracted. The questions which did not contain PI, but where PI was provided in the answer were taken into further examination and calculated as one item of the analysis. In total, PI was found in only 103 questions or answers, and consequently $50 \%$ of all questions were excluded from the analysis. This is the first indication that both demand and supply of PI are rather low. In total, 69 questions and 92 answers contained one or more items of PI.

The majority of questions and answers with PI ( $\mathrm{N}=72$ or $70 \%)$ were given in written form. Out of $69 \mathrm{MPs}^{\prime}$ questions with PI, 51 were posed in written form and only

1 http://edoc.sabor.hr/ZastupnickaPitanja.aspx. 
18 were posed during the Parliamentary sessions. It should be borne in mind that the sessions are often broadcast on public television, with journalists who report on the Parliamentary discussion. The lack of demand for PI suggests that information is not used either by the opposition or the governing parties.

In regard to the content of the MPs' questions, the analysis showed that the questions are directed more towards 'daily politics' than to receiving 'real' PI, and sometimes demand for PI was led by political interests (such as to criticize or to emphasize the success of the government). In general, if PI is requested, the administration will provide more information if there are official records that can be used to answer the question.

Examples of questions that do not demand and those that demand (with an answer) PI:

Example 1: 'How can the issue of transportation of school children from the village of Binjska Greda who are attending elementary school in Komarevo be resolved...'? (Question to the Minister of Science, Education and Sports, January 8, 2015). Example 2: 'How many water concessions have been awarded and to which companies? How much profit has the state made per concession annually and how much profit has the state made in total'? (Question to the Ministry of Agriculture, March 5, 2015); 'There have been 42 concessions so far ... In 2014 the total amount of profit made on the basis of water concessions amounted to HRK 11,293,199.38, out of which $50 \%$ is central state budget profit ... The amount of profit made per concession annually can be found in the appendix to this answer' (Answer by the Minister, March 26, 2015).

\subsection{The relation between the demand and supply of performance information}

According to the first hypothesis, demand for PI by MPs is lower than the supply of PI by the administration. The data presented in Table 1 confirm the hypothesis. MPs asked for PI in only $67 \%(\mathrm{~N}=69)$ of the selected 103 questions while the administration provided PI in almost $90 \%(\mathrm{~N}=92)$ of the answers. If compared with the total number of questions posed in the first six months of 2015 ( $N=206)$, it can be concluded that MPs asked for PI in only 33\% of the questions, while the administration was able to provide some PI in $45 \%$ of the answers. Additionally, the statistical chi-square test confirms that there is a significant statistical difference between questions and answers, so it is statistically verified that the supply of PI exceeds its demand ${ }^{2}$.

Table 1: PI contained in the questions and answers

\begin{tabular}{|c|c|c|c|}
\hline \multicolumn{2}{|c|}{ Total selected questions (questions or answers with PI) } & \multicolumn{2}{|l|}{$\mathrm{N}=103$} \\
\hline Questions request $\mathrm{PI}$ & $\mathrm{N}=69(67 \%)$ & Answers supply PI & $\mathrm{N}=92(89 \%)$ \\
\hline Total questions and answers & & $\mathrm{N}=\mathbf{2 0 6}$ & \\
\hline Questions request $\mathrm{PI}$ & $\mathrm{N}=69(33 \%)$ & Answers supply PI & $\mathrm{N}=92(45 \%)$ \\
\hline
\end{tabular}

Source: Authors

2 Chi-square test calculated in Excel (chi test), $\mathrm{p}=0.001781719$. 
Almost the same conclusion can be drawn if questions are disaggregated into specific types of PI (Table 2) 3 . MPs requested a total of 126 items of PI and the administration was able to provide a total of 186 items of PI. This is especially visible in the case of outputs. Namely, MPs asked only for 57 items of output information and the administration supplied as many as 98 . This means that the public administration is oversupplying MPs with output information they have not asked for.

However, the request for outcome information exceeds its supply - 16 questions contained outcome information, and they were provided in only 12 answers. Yet, the MPs asked for 16 pieces of outcome information and the administration was able to provide 21 pieces, although in a lesser number of answers. Thus, it seems that MPs have an interest in receiving outcome information but the administration is not able to provide all of it, and provided outcome information which was not asked for by the MPs. This is also in line with previous research, according to which Croatian public organizations are able to measure outputs, but face problems with the measurement of outcomes, efficiency, cost-effectiveness and quality (Manojlović, 2016, pp. 251-252).

Table 2: Items of PI per type in questions/answers

\begin{tabular}{|c|c|c|c|c|c|c|c|}
\hline \multirow{2}{*}{$\begin{array}{c}\text { Items of PI } \\
\text { in the question }\end{array}$} & \multicolumn{3}{|c|}{$\begin{array}{l}\text { Number of questions } \\
\text { containing PI }\end{array}$} & \multirow{2}{*}{$\begin{array}{c}\text { Items of PI } \\
\text { in the answer }\end{array}$} & \multicolumn{3}{|c|}{$\begin{array}{l}\text { Number of answers } \\
\text { containing PI }\end{array}$} \\
\hline & Input & Output & Outcome & & Input & Output & Outcome \\
\hline 1 & 16 & 26 & 16 & 1 & 30 & 41 & 8 \\
\hline 2 & 3 & 7 & 0 & 2 & 6 & 9 & 2 \\
\hline 3 & 2 & 3 & 0 & 3 & 4 & 7 & 1 \\
\hline 4 & 5 & 2 & 0 & 4 & 2 & 1 & 0 \\
\hline 5 & 1 & 0 & 0 & 5 & 1 & 1 & 0 \\
\hline$>5$ & 0 & 0 & 0 & $>5$ & 0 & 1 & 1 \\
\hline$\sum$ questions with PI & 27 & 38 & 16 & $\sum$ answers with $\mathrm{PI}$ & 43 & 60 & 12 \\
\hline$\sum$ items of PI & 53 & 57 & 16 & $\sum$ items of PI & 67 & 98 & 21 \\
\hline
\end{tabular}

Source: Authors

Further, the analysis shows that 47 questions (out of 103 selected for analysis) were not connected with their respective answers (cf. Van Dooren, 2004). The reasons are grouped in two categories: (1) the question itself does not demand any PI and thus the PI provided in the answer is not connected with the question (78\% of cases); (2) the answer does not contain PI (22\% of cases). Since the main reason for the disconnection is the absence of demand in the question, this is further proof of the lack of interest expressed by MPs and, as a consequence, the lower level of demand (Table 3).

However, even in the remaining 56 questions, the connection between the question and its respective answer is not the same. As Table 3 shows, in $59 \%$ of cases a

3 One question/answer may contain multiple items of PI so their sum is higher than the total number of questions and answers. 
full quantitative connection between the question and answer has been established - the administration supplies the MP with the exact amount of information he/she asked for. But, in the remaining cases, the administration gives more PI than asked for (over supply of PI) or less information than requested (undersupply of PI). The undersupply is a less important category, containing only eight questions $(14 \%)$ and thus allowing the conclusion that the quantitative undersupply of PI is a rather rare situation.

Table 3: Connection and non-connection between questions and answers

\begin{tabular}{|c|c|c|c|}
\hline \multicolumn{4}{|c|}{ Connection between questions and answers } \\
\hline & & Questions/answers wi & \\
\hline \multicolumn{2}{|l|}{ Connected } & & $56(54 \%)$ \\
\hline \multicolumn{2}{|l|}{ Non-connected } & & $47(46 \%)$ \\
\hline \multicolumn{2}{|l|}{$\Sigma$} & & $103(100 \%)$ \\
\hline \multicolumn{2}{|l|}{ Connected } & \multicolumn{2}{|c|}{ Not-connected } \\
\hline \multicolumn{2}{|l|}{ Full quantitative connection } & No PI in the question & $36(78 \%)$ \\
\hline Undersupply of PI & $8(14 \%)$ & \multirow{2}{*}{ No PI in the answer } & \multirow{2}{*}{$11(22 \%)$} \\
\hline Oversupply of PI & $15(27 \%)$ & & \\
\hline$\Sigma$ & $56(100 \%)$ & $\Sigma$ & $47(100 \%)$ \\
\hline
\end{tabular}

Source: Authors

\subsection{The relationship between MPs' personal characteristics and the demand for performance information}

According to the second hypothesis, higher demand for PI is expected from the better educated but politically inexperienced MPs and from those belonging to the opposition parties. In the 2011-2015 period (the $7^{\text {th }}$ convocation of the Croatian Parliament), there were $151 \mathrm{MPs}$. Out of these, only $40 \mathrm{MPs}$ (26.5\%) posed questions requiring certain PI, which proves again that MPs' interest in receiving PI is low.

Knowing that there were 69 questions demanding some PI, this means that some of the MPs posed more than one question demanding PI (1.7 questions on average). However, the analysis takes into consideration all MPs demanding PI, irrespective of the number of questions posed.

Although previous results show that MPs' interest in PI is low, further results are not that unequivocal. Looking at the education level of Croatian MPs (Table 4), the majority have a university degree or higher education. The same is valid for MPs demanding PI - 24 out of $40(60 \%)$ MPs demanding PI have a higher level of education which points to the fact that better-educated MPs require more PI.

However, when looking at the share of MPs within the same educational level, it is evident that only $15.66 \%$ of MPs with a university degree demand PI. On the other hand, almost $50 \%$ of MPs only with three years vocational education demanded PI, followed by $40 \%$ of MPs with the highest academic titles. 
Table 4: Demand for performance information according to the MPs' educational level

\begin{tabular}{lccccc}
\hline Educational level & Total MPs & $\%$ & MPs demanding PI & $\%$ & $\begin{array}{c}\text { Share of MPs demanding } \\
\text { Pl within the category (\%) }\end{array}$ \\
\hline Secondary school & 22 & 14.57 & 7 & 17.5 & 31.82 \\
Three years vocational education & 19 & 12.58 & 9 & 22.5 & 47.37 \\
University education & 83 & 54.97 & 13 & 32.5 & 15.66 \\
Higher titles (Master of Science, PhD) & 27 & 17.88 & 11 & 27.5 & 40.74 \\
$\Sigma$ & 151 & 100 & 40 & 100 & \\
\hline
\end{tabular}

Source: Authors

Therefore, MPs with the highest and lowest education levels demand most PI, while the average educated (in this case, having a university degree) are less inclined to request PI.

When it comes to political experience, the level of PI demand decreases with political experience $-24(60 \%)$ out of $40 \mathrm{MPs}$ requesting PI were serving their first term in Parliament or they were substitutes to other MPs and thus they joined Parliament later. A total of $34 \%$ of MPs serving their second term requested PI, which could indicate that the demand for PI grows with political experience. However, the fact that only $16 \%$ of MPs serving more than two terms request PI seems to indicate that the interest in PI diminishes with longer political experience (Table 5).

Table 5: Demand for performance information according to the MPs' political experience

\begin{tabular}{lccccc}
\hline & Total MPs & $\%$ & MPs demanding PI & $\%$ & $\begin{array}{c}\text { Share of MPs demanding } \\
\text { PI within the category (\%) }\end{array}$ \\
\hline Less than one term/one full term & 91 & 60.26 & 24 & 60 & 26.37 \\
Two terms & 35 & 23.18 & 12 & 30 & 34.29 \\
More than two terms & 25 & 16.56 & 4 & 10 & 16.00 \\
$\Sigma$ & 151 & 100 & 40 & 100 & \\
\hline
\end{tabular}

Source: Authors

The data are more unequivocal when it comes to the divide of ruling-opposition parties. More than $60 \%$ of MPs demanding PI belong to opposition parties, thus proving that PI is mostly used to attack the Government and show its shortfalls than to celebrate its success (Table 6).

Table 6: Demand for performance information according to the ruling parties-opposition divide

\begin{tabular}{lccccc}
\hline & Total MPs & $\%$ & MPs demanding PI & $\%$ & $\begin{array}{c}\text { MPs demanding PI/ Total number } \\
\text { of MPs ruling/opposition (\%) }\end{array}$ \\
\hline Ruling parties + supporters & 81 & 53.64 & 15 & 37.5 & 18.51 \\
Opposition & 70 & 46.36 & 25 & 62.5 & 35.71 \\
$\Sigma$ & 151 & 100 & 40 & 100 & \\
\hline
\end{tabular}

Source: Authors 
All in all, it seems that the second hypothesis cannot be fully confirmed. MPs belonging to the opposition parties are those requiring more PI, but the results are less conclusive when it comes to their educational level and political experience. The results show an approximately equal demand by both the best and least educated MPs. When it comes to political experience, demand is lowest from the most experienced MPs.

\section{Discussion}

The results of the empirical research show that the demand for PI by MPs is lower than its supply by the administration, and thus it can be concluded that MPs' interest in receiving PI is not high, not even for political purposes. However, there is an evident oversupply of output information which the MPs have not asked for.

Although the theoretical postulates state that 'outputs are never an end in themselves in the public sector (...) and ultimate effects or outcomes are a central focus' (Bouckaert and Halligan, 2008, p. 16), in the Croatian public sector this is still not the case. However, it seems that this is not only a Croatian problem, since Grossi, Reichard and Ruggiero (2016, p. 597) presented evidence from the German and Italian local levels where PI provided in budgets is still input-, process- and partially output-oriented with a great lack of outcome information. The explanations are twofold: complicated methods for quality and outcomes measurement and the traditional focus of bureaucrats and politicians on input and procedure. Both explanations are valid for Croatia.

In addition, according to Jansen (2008), politicians have a different perspective on performance than managers (public administration). They are interested in the citizens' and financial perspective of performance, while the administration is interested in the internal and output perspective. This can also explain the existing discrepancy between the oversupplied output information and the low occurrence of outcome information.

Several conclusions can be drawn from the qualitative view of the content of the questions and answers. First, the quality of questions is disputable, as they are very often formed without a genuine intention to obtain PI, and are used to fulfill the daily political agenda, either to support the governing party or to provoke it. Second, the answers of the administration are far more detailed (and sometimes give more information than requested) if official records exist and can be used to answer the question. If official data do not exist, the administration will not provide a full answer to the question. Third, if the required information is not available, the administration will try to avoid answering by providing information on future plans. This tendency has been noticed by MPs as well: 'I beg you not to indicate future plans, projects and wishes in your answer...' (Question to the Ministry of Economy, January 30, 2015).

Overall, two issues seem to emerge as explanations for this state of affairs. First, the performance management system is still under development. Performance management consists of performance measurement but also of the incorporation of PI into the management and policy cycle and the use of such information (Van Dooren, Bouckaet and Halligan, 2015). Croatian public administration is able to measure some perfor- 
mance dimensions, but there are shortfalls, especially in the measurement of outcomes and cost effectiveness (Manojlović, 2016). This research indicates that MPs show low interest in demanding PI, which can potentially lead to their low usage of PI. Problems in PI usage can also be explained because accountability for performance is underdeveloped (Lalić Novak, Džinić and Manojlović, 2015), meaning that PI is not used for accountability purposes. Problems in the performance management system are stated in the 'Strategy for the Development of Public Administration 2015-2020' (Official Gazette 70/15) and in other research (cf. Koprić, Džinić and Manojlović, 2016).

This raises two important questions. First, what is the future of performance management in Croatia? The evidence from a number of studies (in Dan and Pollitt, 2015) states that in Central and Eastern European countries performance management leads to positive effects, but its implementation needs to be incremental and adopted to fit the administrative capacity of each country. If applied in Croatian circumstances, this means that the incremental introduction of performance measurement can lead to its institutionalization, which could also influence demand, as well as the use of performance management. According to Padovani, Yetano and Levy Orelli (2010), who studied the introduction of a performance management system in selected local units in Spain and Italy, the appropriate time for the system to be institutionalized is five years. The data presented in this paper show that in Croatian circumstances the time span has to be longer, especially for the measurement of a complex performance dimension such as outcomes or quality. However, the factor of economic crisis needs to be taken into account. According to Bjørnholt, Bækgaard and Houlberg (2016), the use of PI amounts to the 'politics of good times', meaning that a lower degree of PI usage can be expected in times of austerity. Since Croatia has experienced severe economic crises lasting for six years and started slowly to recover only at the end of 2014 (Koprić, Škarica and Manojlović, 2018), the further institutionalization and usage of PI can be expected only in the future.

Second, is there any purpose in supplying MPs with PI that they do not ask for? It seems that the oversupply of PI that the MPs are receiving could have a positive effect. Namely, Hammerschmid, Van de Walle and Štimac $(2013$, p. 6) have proven that information availability (the degree of implementation of performance management) is the most important factor for public managers' use of PI. In the same way, the availability of PI could stimulate its use by MPs.

The second issue concerns the influence of the Europeanization process on national institutions in Croatia. The actions of the executive at the European level are beyond the control of national parliaments, hence 'European integration has meant a decrease in the power of national parliaments and an increase in the power of executives' (Follesdal and Hix, 2006, p. 534). Different authors suggest that we are witnessing domestic 'deparliamentarization' (Brouard, Costa and König, 2012).

A similar argument could be applied in the Croatian context. Executives had a leading role in the long process of accession negotiations, while Parliament was somehow just following a path. A similar situation is being translated into the realm 
of the demand and supply of PI - executives provide information, while Parliament rather passively waits to receive it.

When it comes to MPs' personal characteristics, the second hypothesis cannot be fully confirmed. MPs belonging to opposition parties demand more PI, but both the best and least educated MPs demand PI. Political experience seems to be important since MPs serving more than two terms are those demanding the least PI.

It is interesting to note that both in Norwegian (Askim, 2009) and Estonian (Raudla, 2012) circumstances the dichotomy of 'belonging to the ruling/opposition spectrum in parliament' has not proven important, while in Croatia there is a higher demand for PI by opposition MPs. Askim (2009) states that other circumstances (such as the within-policy conflict, within-policy completion, and the message that the PI carries) probably have an effect when combined with the ruling/opposition party divide, but these factors were not tested. Raudla (2012, p. 1012) explains that 'opposition legislators feel powerless about making significant changes to the budget, so they do not see the value in immersing themselves in $\mathrm{PI}^{\prime}$. The explanation of different results in Croatian circumstances may stem from the methodology implemented and the different research topics. Namely, Raudla conducted interviews with members of the finance committee in the Estonian Parliament, while Askim examined questionnaires filled in by 750 local councilors. In this research, the content analysis was implemented and only the demand for PI, not its usage, was examined. The implementation of other research methods, such as interviews, could show whether there are differences in the actual use of requested PI by ruling and opposition MPs.

When trying to explain the discrepancy between ruling/opposition MPs in simply demanding PI, ter Bogt's (2004, p. 241) finding can be useful. Ter Bogt has shown that councilors (but presumably also MPs) prefer informal and verbal information obtained directly from managers. Consequently, it is reasonable to expect ruling parties' MPs to receive this type of information more easily and thus they are not forced or stimulated to pose parliamentary questions to their party colleagues. On the other hand, MPs belonging to the opposition cannot obtain such informal information and hence they are forced to pose parliamentary question in order to receive the PI they need.

\section{Conclusion}

The research goal of this paper was to examine the demand and supply of PI in the Croatian public administration and in the political system by examining MPs' questions posed to the administration and the answers there to. The empirical research shows that demand for PI by MPs is lower than its supply by the administration. However, there is an oversupply of output information which the MPs did not ask for, but the information on outcomes is completely marginalized. In terms of MPs requiring PI, the data point to the fact that higher demand comes from MPs belonging to the opposition parties and those who are politically inexperienced, while the results on the educational background are not conclusive.

Two issues will be further discussed. First, the system of performance management is still under development, but the oversupply of PI could have a positive effect 
on PI usage. Second, there is an increase in the power of executives and the passivity of parliaments, which may be a result of the Europeanization process.

However, the qualitative insight into MPs' questions shows that their quality is disputable since they are very often formed without a genuine intention to obtain PI. Thus, this paper opens the floor for further research, especially that using qualitative research methods such as interviews to examine the usage of PI by MPs and their real intention when posing a certain question. In addition, since the performance measurement system is still in a rather early stage of development, Croatia will be a good example for conducting longitudinal studies.

\section{References:}

1. Askim, J., 'The Demand Side of Performance Measurement: Explaining Councillors' Utilization of Performance Information in Policymaking', 2009, International Public Management Journal, vol. 12, no. 1, pp. 24-47.

2. Askim, J., 'Determinants of Performance Information Utilization in Political Decision Making', in Van Dooren, V. and Van de Walle, S. (eds.), Performance Information in the Public Sector - How It Is Used, Chippenham and Eastbourne: Palgrave Macmillan, 2011, pp. 125-139.

3. Bjørnholt, B., Bækgaard, M. and Houlberg, K., 'Does Fiscal Austerity Affect Political Decision-Makers' Use and Perception of Performance Information?', 2016, Public Performance \& Management Review, vol. 39, no. 3, pp. 560-580.

4. Bouckaert, G. and Halligan, J., Managing Performance: International Comparisons, New York: Routledge, Taylor \& Francis Group, 2008.

5. Brouard, S., Costa, O. and König, T, 'Delors' Myth: The Scope and Impact of the Europeanization of Law Production', in Brouard, S., Costa, O. and König, T. (eds.), The Europeanization of Domestic Legislatures: The Empirical Implications of the Delors' Myth in Nine Countries, New York: Springer-Verlag, 2012, pp. 1-19.

6. Dan, S. and Pollitt, C., 'NPM Can Work. An Optimistic Review of the Impact of New Public Management Reforms in Central and Eastern Europe', 2015, Public Management Review, vol. 17, no. 9, pp. 1305-1332.

7. de Lancer Julnes, P. and Holzer, M., 'Promoting the Utilization of Performance Measures in Public Organizations: An Empirical Study of Factors Affecting Adoption and Implementation', 2001, Public Administration Review, vol. 61, no. 6, pp. 693-708.

8. Finish Ministry of Finance, 'Government for the Future. Austria, Finland, Scotland, Sweden, United Kingdom', Helsinki, 2013, [Online] available at http://vm.fi/documents/10623/307541/Governments+for+the+Future\%2C+Main+Report+November+2013+pdf.pdf/8947d7cd-5713-4a1b-bb4e-5fe25bc72ab5, accessed on June 15, 2017.

9. Follesdal, A. and Hix, S., 'Why There Is a Democratic Deficit in the EU: A Response to Majone and Moravcsik', 2006, Journal of Common Market Studies, vol. 44, no. 3, pp. 533-562.

10. Grossi, G., Reichard, C. and Ruggiero, P., 'Appropriateness and Use of Performance Information in the Budgeting Process: Some Experiences from German and Italian $\mathrm{Mu}-$ nicipalities', 2016, Public Performance \& Management Review, vol. 39, no. 3, pp. 581-606. 
11. Hammerschmid, G., Van de Walle, S. and Štimac, S., 'Internal and External Use of Performance Information in Public Organizations: Results from an International Survey', 2013, Public Money E Management, vol. 33, no. 4, pp. 261-268.

12. Jansen, E.P., 'New Public Management: Perspectives on Performance and the Use of Performance Information', 2008, Financial Accountability E Management, vol. 24, no. 2, pp. 169-191.

13. Koprić, I., Škarica, M. and Manojlović, R., 'Local Public Services and Austerity Measures in Croatia: Adaptations of the Resilient Social Model through the Central-Local Power and Blame Games', in Lippi, A. and Tsekos, T. (eds.), Local Public Services in Times of Austerity across Mediterranean Europe, Chippenham and Eastbourne: Palgrave Macmillan, 2018, pp. 167-191.

14. Koprić, I., Džinić, J. and Manojlović, R. (eds.), ‘Upravljanje kvalitetom i učinkovitošću $\mathrm{u}$ javnoj upravi' (Quality and Performance Management in Public Administration), Zagreb: Institute for Public Administration, 2016.

15. Koprić, I., Marčetić, G., Musa, A., Đulabić, V. and Lalić Novak, G., Upravna znanost - Javna uprava u suvremenom europskom kontekstu (Administrative Science - Public Administration in European Context), Zagreb: Faculty of Law, University of Zagreb, 2014.

16. Lalić Novak, G., Manojlović, R. and Džinić, J., 'From Traditional Models of Accountability to Accountability for Performance: Inter-sector Comparison in Croatian Public Administration,' in Lazarević, M., Marović, J. and Kacarska, S. (eds.), Improving Performance of Public Administration: Current Experiences and Future Perspectives, Belgrade: Think for Europe' Network of Think Tanks and EU Policy Research Centres in South East Europe (TEN), 2015, pp. 85-105

17. Manojlović, R., 'Organizational Size as a Determining Factor of Performance and Quality Measurement: Lessons for the Croatian Local Self-Government', 2016, Croatian and Comparative Public Administration, vol. 16, no. 2, pp. 237-266.

18. Mason, D., Hillenbrand, C. and Money, K., 'Are Informed Citizens More Trusting? Transparency of Performance Data and Trust Towards a British Police Force', 2014, Journal of Business Ethics, vol. 122, no. 2, pp. 321-341.

19. Ministry of Finance, Smjernice za upravljačku odgovornost (Guidelines for Managerial Responsibility Development), 2012, Zagreb: Ministry of Finance, [Online] available at http://www.mppi.hr/UserDocsImages/Smjernice\%20za\%20upravljacku\%20odgovornost.pdf, accessed on June 15, 2017.

20. Moynihan, D., The Dynamics of Performance Management: Constructing Information and Reform, Washington: Georgetown University Press, 2008.

21. Moynihan, D., 'Through a Glass, Darkly. Understanding the Effects of Performance Regimes', 2009, Public Performance and Management Review, vol. 32, no. 4, pp. 592-603.

22. Moynihan, D. and Pandey, S.K., 'The Big Question for Performance Management: Why Do Managers Use Performance Information?', 2010, Journal of Public Administration Research and Theory, vol. 20, no. 4, pp. 849-866.

23. Padovani, E., Yetano, A. and Levy Orelli, R., 'Municipal Performance Measurement and Management in Practice: Which Factors Matter?', 2010, Public Administration Quarterly, vol. 34, no. 4, pp. 591-635. 
24. Raudla, R., 'The Use of Performance Information in Budgetary Decision-Making by Legislators: Is Estonia Any Different?', 2012, Public Administration, vol. 90, no. 4, pp. 1000-1015.

25. Sterck, M. and Scheers, B., 'Trends in Performance Budgeting in Seven OECD Countries', 2006, Public Performance \& Management Review, vol. 30, no. 1, pp. 47-72.

26. Ter Bogt, H., 'Politicians in Search of Performance Information? - Survey Research on Dutch Aldermen's Use of Performance Information', 2004, Financial Accountability $\mathcal{E}$ Management, vol. 20, no. 3, pp. 221-252.

27. Van de Walle, S. and Roberts, A., 'Publishing Performance Information: An Illusion of Control?', in Van Dooren, W. and Van de Walle, S. (eds.), Performance Information in the Public Sector - How It Is Used, Chippenham and Eastbourne: Palgrave Macmillan, 2011, pp. 211-226.

28. Van de Walle, S. and Van Dooren, W., 'Introduction: Using Public Sector Performance Information', in Van de Walle, S. and Van Dooren, W. (eds.), Performance Information in the Public Sector - How It Is Used, Chippenham and Eastbourne: Palgrave Macmillan, 2011, pp. 1-8.

29. Van Dooren, W., 'Supply and Demand of Policy Indicators. A Cross-sectoral Comparison', 2004, Public Management Review, vol. 6, no. 4, pp. 511-530.

30. Van Dooren, W., Bouckaert, G. and Halligan, J., Performance Management in the Public Sector, New York: Routledge, Taylor \& Francis Group, 2015.

31. Weber, R.P., Basic Content Analysis, $2^{\text {nd }}$ edition, Newbury Park, USA: Sage Publication, 1990. 


\section{TRANSYLVANIAN REVIEW}

Mojca BIŠČAK

Jože BENČINA

The Impact of HRM Practices on the Performance of Municipalities.

The Case of Slovenia

Oana Maria BLAGA

Răzvan Mircea CHERECHEȘ

Cătălin Ovidiu BABA

A Community-Based Intervention for Increasing Access

to Health Information in Rural Settings

Emil BOC

The Development of Participatory Budgeting Processes in Cluj-Napoca

Andrei CHIRCĂ

Dan Tudor LAZĂR

Students' Visitors - Among the Unexplored Types of Local Tourism?

Min-Hyu KIM

65 Factors Influencing the Propensity to Contract Out Health and Human Services in Response to Government Cutbacks: Evidence from US Counties

Mateusz LEWANDOWSKI

85 Organizational Drivers of Performance Information Use:

The Perspective of Polish Local Governments

Romea MANOJLOVIĆ TOMAN

Goranka LALIĆ NOVAK

100 The (Lack Of) Demand for Performance Information by the Croatian Parliament Oleksiy POLUNIN

116 The Case of Ukrainian Corruption: Phenomenology and Psychological Insides 